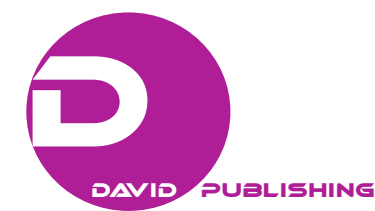

\title{
No More Excuses - Personality Traits and Academic Dishonesty in Online Courses
}

\author{
Yovav Eshet \\ The Department of Multi-Disciplinary Studies \\ Zefat Academic College \\ Zefat, Israel \\ Keren Grinautski \\ The Department of Multi-Disciplinary Studies \\ The Western Galilee College \\ Akko, Israel \\ Yehuda Peled \\ Department of Information Science \\ The Western Galilee College \\ Akko, Israel \\ Casimir Barczyk \\ School of Management \\ Purdue University, Calumet, USA.
}

\begin{abstract}
Academic dishonesty is a disturbing issue in higher education that has been worsening over the years, especially with the appearance of the internet and the e-learning education. This new technology exposes students to the opportunity of using online bank exams and term papers and increases their tendency to cheat. This study investigates student academic dishonesty in the context of traditional and distance-learning courses in higher education. Data from 1,365 students enrolled in academic institutes in the U.S.A and Israel were surveyed to assess their personality and their willingness to commit various acts of academic misconduct. The findings indicate that in both countries dishonest behaviors are greater in face-to-face courses than in online courses. In addition, both American and Israeli students identified with the personality trait of Agreeableness showed a negative correlation with academic dishonesty. Furthermore, Israeli students identified with the personality traits of Conscientiousness and Emotional Stability demonstrated a negative correlation with academic dishonesty. In contrast, the personality trait of Extraversion among American students was found in a positive correlation with academic misconduct. Implications for further research are discussed.
\end{abstract}

Keywords: Academic Dishonesty, Personality Traits, OCEAN, Online Courses.

Corresponding author: Yovav Eshet, The Department of Multi-Disciplinary Studies, Zefat Academic College, Zefat, Israel. 


\section{Introduction}

Academic dishonesty has been described as an act of cheating, deception and violation of rules for a personal gain or advantage [1], [2] done by the student, "a conscious effort to use proscribed data and/or resources on exams or written work submitted for academic credit" [3]. Before engaging in unethical academic behavior, a student has to make a rational decision that the benefit of cheating worth the risk of getting caught [4]. There are two types of academic dishonesty - active and passive, both including an intention for cheating. Active includes an act for raising a student's grade, whereas passive includes a behavior of assisting other student to raise his grade [5].

Researchers have shown that academic dishonesty has been worsened over the years [6], [7], [4], [8], and that cheating is an epidemic phenomena across most college campuses [9], [10], [11]. The development of information technology and the accessibility of academic material on the internet made it easier to engage in cheating and in plagiarism [12], [13], [14], and [15]. Furthermore, assignments and papers are available for purchase to students who seek for it [16].

In addition, the growth of technology encouraged the existence of online courses and distant education. According to the National Center for Education Statistics [17], almost 4.3 million undergraduate students are participating in online courses per year. There is a notion that it is easier to cheat when participating in distance learning classes [18], and both students and faculty are aware of the intensity of this phenomenon compared to traditional courses [11], particularly where there is little or no personal contact between students and faculty [19], [20]. Similarly, Kelley and Bonner [21] suggested that students who feel close to their professors tend to be more honest. However, in the online learning environment the ability for faculty to develop a strong rapport with students becomes more difficult. Students who feel "distant" from others seem to have higher tendency to perform deceptive behaviors, such as cheating [22], [23]. Online courses, in contrast to traditional classroom courses, may serve to exacerbate these feelings of separation and, thus, may contribute to higher incidence of academic dishonesty [24], [25].

The research literature shows that academic dishonesty is influenced not only by situational factors (circumstantial and contextual) [26], such as the teaching method - on-line vs. traditional classrooms, as we mentioned above, but individual factors as well (demographic, psychosocial and academic characteristics of students) [27]. One of these individual factors is related to various personality traits.

\section{Students' Personality as a Predictor of Academic Dishonesty}

Research regarding the relationship between unethical academic behavior and personality traits includes several studies, while each study uses a different measure of academic dishonesty. Hence, the results are often contradicting [28], [29] and [30]. Although the ability of the 'Big Five' personality traits measure was proved effective in explaining unethical behaviors [31], and would be expected to have a direct impact on the level of students' cheating behavior [32], it is not frequently used in the context of academic dishonesty and most researches who did use it addressed only few traits instead of the whole model [30], [31]. Below are explained the personality traits of the "Big Five" model in the context of academic dishonesty.

Big Five personality traits include Extraversion, Conscientiousness, Agreeableness, Neuroticism and Openness to experience [33]. The personality trait of Extraversion is characterized as the tendency to be talkative, assertive, energetic, sensation-seeking [36] and looking for excitement [35], [36]. Those individuals 
seek power, status and recognition [37], therefore socializing with peers [38], [37], [39], [40] and building relationships for future necessity [41]. Introverts (which is the reverse of extraverts) prefer to be alone, and thus, they are less likely to be influenced by others' cheating behavior [42]. In contrast, extraverts are more impulsive and less self-controlled [43]. This tendency causes them to be more vulnerable to an unethical behavior as they are prone to imitate others [44]. This being said, it's important to note that the studies that addressed this trait's effect on academic dishonesty are scarce and their results are contradicting [34]. Some of them have found that extraversion was positively related to cheating behavior and academic dishonesty [45], [46], [47], while others did not find this impact on the level of cheating tendency among students [32].

Conscientiousness describes organized and responsible individuals, who think and plan before taking any action and follow society's rules and norms. Accordingly, the Conscientious student may be described as dependable, achievement-oriented, persistent, responsible and honest [39]. He operates as an effective regulator of his own actions, who is able to restrain and regulate behavior through "effortful control", thus, he can resist cheating [48] and hold more negative attitudes towards academic dishonesty [49]. He acts with high productivity and less deviance [51]. As opposed, student with lower conscientiousness is expected to be irresponsible, disorganized and impulsive. As a consequence, these characteristics might lead to poorer studying skills, which in turn might increase the tendency to cheat. Accordingly, research has found that this trait can foresee unethical behaviors [51], [52], [53].

Agreeableness involves cooperating with others and maintaining harmony. Individuals that are high on agreeableness have high ability to create good relationship [54] and peruse group norms [55]. In contrast, those that are low in this trait are expected to be lacking in these behaviors. Although research has not found a significant impact of agreeableness on academic dishonesty in general [32], the study of Williams et al. [34] found that agreeableness was negatively correlated with a particular unethical academic behavior of plagiarism. Thus, it can be expected that individuals who are high in agreeableness will follow the rules and norms and will less implement deviant behavior.

Neuroticism is a personality trait that describes an individual with a non-constructive emotionality [39], [33]. Thus, not surprisingly, in research literature it has been associated with organizational deviance [51] and has a negative impact on the tendency to engage in unethical academic behaviors and in cheating [34]. Emotional Stability (which is the reverse of neuroticism) reflects students' enhanced feeling of competence and a sense of security [39], which allows them to be more relaxed, unworried and less likely to become strained in stressful conditions, such as tests or deadlines. Thus, these students are considered to be less inclined toward cheating behaviors [49].

Finally, high Openness to Experience includes tendencies toward intellectualism, creativity, imagination, and broad-mindedness [39], [56], cognitive capability and high training aptitude [39]. Research findings show that this personality trait is related to academic success and to learning orientation, reflecting desire to understand concepts and master material [49]. Furthermore, learning orientation predicted lower inclination to cheat [50].

Empirical research confirmed the relationship between personality traits and individual tendency to cheat for Extraversion and for Neuroticism [30]. In addition, low Conscientiousness and low Agreeableness was found as predicting cheating behaviors as well [38]. More recently, Day et al. [49] examined the effects of Conscientiousness, Emotional Stability, and Openness to Experience on students' attitudes towards cheating, combined with two context variables, e.g., classroom culture and pedagogy. The findings showed that while 
Conscientiousness was the sole personality measure that directly predicted negative attitudes towards cheating, Emotional Stability and Openness to Experience also lead to negative attitudes towards academic misconduct, however, only when combined with classroom context variables. Based on the above, we hypothesize that there will be differences in the level of academic dishonesty based on the various personality traits especially among e-learners.

\section{Method}

\section{Participants}

The sample consisted of 1,574 participants with 803 from two American academic institutes and 771 from four Israeli academic institutes. $65 \%$ of the participants were women and $35 \%$ were men. The age ranged from 17 to 59 (the mean was 26.4 years). $26 \%$ of the participants were freshmen, $32 \%$ - sophomores, $20 \%$ - juniors, $19 \%$ - seniors, and 3\% were graduate students. $46 \%$ were Christians, $38 \%$ were Jews, and $16 \%$ were Muslims. $13 \%$ of the participants were excluded from the analysis because their surveys were incomplete or carelessly completed. Therefore, the final data set consisted of 1,365 participants.

\section{Survey Instrument}

A three part survey instrument was used in the current study. Part 1 included the TIPI scale developed by [59], which was consisted of 10 items assessing the participants' personality traits. The reliability of this questionnaire, measured by Cronbach's alpha, was 0.72. Part 2 was consisted of the questions that examined academic integrity using the Academic Integrity Inventory [57]. These questions investigated the students' likelihood to engage in various forms of academic misconduct. The instrument was validated by [57] and reliability of this questionnaire, measured by Cronbach's alpha, was 0.75 . Part 3 presented a series of socio-demographic questions.

\section{Procedure}

In order to encourage the participants to think in the frame of a specific type of course, we administered a printed version of the survey instrument in the traditional face-to-face courses and an on-line version of the survey instrument in the e-learning courses. The survey instruments were coded and grouped according to the location of the participants' college or university (USA or Israel). The questionnaires were distributed at the end of the courses.

\section{Results}

Table 1 summarizes the results of Independent Sample T-test analyses, which indicate that there were statistically significant differences in students' likelihood to engage in academic dishonesty based on the type of course in which they were enrolled. Specifically, it was found that students in face-to-face courses were more likely to engage in acts of academic dishonesty than their counterparts in e-learning courses.

Table 1

Differences in academic dishonesty by course type and country

\begin{tabular}{|c|c|c|c|c|c|c|}
\hline Country & Course type & $\mathrm{N}$ & Mean & S.D. & T-Test & $\mathrm{F}$ \\
\hline \multirow{2}{*}{ USA } & E-learning & 287 & 1.61 & 0.52 & \multirow{2}{*}{$12.70^{* * *}$} & \multirow{4}{*}{$57.16^{* * *}$} \\
\hline & Face-to-Face & 470 & 2.16 & 0.66 & & \\
\hline \multirow{2}{*}{ Israel } & E-learning & 293 & 1.78 & 0.60 & \multirow{2}{*}{$5.33^{* * *}$} & \\
\hline & Face-to-Face & 315 & 2.52 & 0.65 & & \\
\hline
\end{tabular}

${ }^{* * *} \mathrm{P}<0.001,{ }^{* *} \mathrm{P}<0.01,{ }^{*} \mathrm{P}<0.05$ 
Based on multiple analysis of variance (MANOVA) analysis we found significant interaction between country and course type $\left[\mathrm{F}_{(1,1361)}=57.16, \mathrm{p}<0.001\right]$.

Table 2

Correlation between personality and academic dishonesty by course type and country

\begin{tabular}{ccccccc}
\hline Country & Course type & 1 & 2 & 3 & 4 & 5 \\
\hline Israel & On-line & -0.038 & $-0.149^{*}$ & $-0.125^{*}$ & $-0.246^{* *}$ & -0.068 \\
$\mathrm{~N}=608$ & Face to face & -0.090 & $0.131-^{*}$ & $-0.237^{* *}$ & $-0.151^{* *}$ & -0.063 \\
USA & On-line & -0.100 & -0.090 & $0.057-$ & 0.121 - $^{*}$ & -0.038 \\
$\mathrm{~N}=757$ & Face to face & -0.016 & -0.040 & $0.031-$ & $-0.114^{*}$ & $0.105^{*}$ \\
\hline
\end{tabular}

$* * * \mathrm{P}<0.001, * * \mathrm{P}<0.01, * \mathrm{P}<0.05$

Note: 1=Openness to Experiences, 2=Emotional Stability, 3=Consciousness, 4=Agreeableness, $5=$ Extraversion

Table 2 shows a significant negative correlation between the personality trait of Agreeableness and academic dishonesty in both countries: Israel and USA. In addition, Israeli students identified with higher Conscientiousness and Emotional Stability demonstrated a significant negative correlation with academic dishonesty. General Linear Model revealed that there is a significant 2-way interaction effect among Israeli students between course type (on-line vs. face-to-face) and the personality trait of Conscientiousness [F=2.058, $\mathrm{p}<0.05$ ] and between course type and the personality trait of Emotional Stability [F=2.047, $\mathrm{p}<0.05$ ]. Interestingly, the personality trait of Extraversion among American students was found in a positive correlation with academic dishonesty, indicating that the tendency to be sociable is correlated with higher inclination to cheat.

\section{Discussion and Conclusion}

Our research found that there is less overall cheating in the virtual than in the traditional classroom settings. These findings are similar to [58] and [59], who explained this phenomenon by the notion that these students may have a higher motivation to learn or able to learn without being dependant on the typical structure of traditional classroom settings.

Our research also indicates that the personality traits of Emotional Stability and Conscientiousness are negatively related to academic dishonesty. These findings are similar to [49] and can be explained by to the notion that students with high Conscientiousness have the proper tendencies to be able to effectively regulate his actions and restrain inappropriate behaviors [48], [51], [52], [53]. Emotional Stability also leads students to be less inclined toward cheating behaviors [49] by enhancing feelings of competence and providing them with sense of security, which in result allow them to successfully cope with stressful situations and conditions [39]. In addition, a significant negative correlation between the personality trait of Agreeableness and academic dishonesty indicates that the more are the students cooperative with others, since the trait of Agreeableness is associated with the ability to create good relationship and to conform with group norms [54], [55], the less are they likely to be academically dishonest.

The results of this research showed that these effects were not observed among American students. This might be explained by cultural differences, as several studies that compared US students with students in Lebanon [60], China [61] and non-Western countries [62], showed that Americans tend to show less acceptance for cheating and to possess higher standards with regard to honesty. 
The main practical implication and contribution of this research are to the process of students' profiling, since we found that students who use cheating practices are less emotionally stable, less conscious and less agreeable. Further research should focus on how to amplify cooperative tasks in online courses in order to reduce Academic Dishonesty. Classroom contextual effects, such as those presented in [49]'s study, may be worth investigating in further research as well, since they seem to contribute to the knowledge regarding the effects of personality traits on attitudes toward cheating [49].

\section{References}

[1] Becker, D. Connolly, J. Lentz, P. and Morrison, J. (2006) 'Using the business fraud triangle to protect academic dishonesty among business students', Leadership Journal, vol. 10, no. 1, pp.37-54, 2006.

[2] Bloodgood, J.M., Turnley, W.H., and Mudrack, P. (2008) 'The influence of ethics instruction, religiosity, and intelligence on cheating behavior', Journal of Business Ethics, vol. 82, pp.557-571.

[3] Sierra, J.J. and Hyman, M.R. (2008) 'Ethical antecedents of cheating intentions: Evidence of mediation', Journal of Academic Ethics, vol. 6, pp.51-66.

[4] Williams, M.S. and Hosek, W.R. (2003) 'Strategies for reducing academic dishonesty', Journal of Legal Studies Education, vol. 21, p.87.

[5] Anitsal, I.M., Anitsal, M. and Elmore, R. (2009) 'Academic dishonesty and intention to cheat: A model on active versus passive academic dishonesty as perceived by business students', Academy of Educational Leadership Journal, vol. 13, no. 2, pp.17-26.

[6] Park, C. (2003). 'In other (people's) words: Plagiarism by university students - literature and lessons', Assessment and Evaluation in Higher Education, vol. 28, pp.471-488.

[7] Pullin, R., Ortloff, V., Casey, S. and Payne, J.B. (2000) 'Analysis of academic misconduct using unobtrusive research: A study of discarded cheat sheets', College Student Journal, vol. 34, p. 616.

[8] Brown, B.S. and McInerney, M. (2008) 'Changes in academic dishonesty among business students in the United States, 1999-2006', International Journal of Management, vol. 25, no. 3, pp.621-632, 2008.

[9] Lambert, E.G. and Hogan, N.L. (2004) 'Academic Dishonesty among Criminal Justice Majors: A Research Note', American Journal of Criminal Justice, vol. 29, no. 1, pp. 1-20.

[10] Tibbetts, S. G. and D. L. Myers. (1999) 'Low Self-Control, Rational Choice, and Student Test Cheating', American Journal of Criminal Justice, vol. 23, no. 2, pp.179-201.

[11] Lanier, M. (2006) 'Academic Integrity and Distance Learning', Journal of Criminal Justice Education, vol. 17, no. 2, pp.244-261.

[12] Comas-Forgas, R. and Sureda-Negre, J. (2010) 'Academic plagiarism: Explanatory factors from students', perspective. Journal of Academic Ethics, vol. 8, no. 3, pp.217-232.

[13] Connors, M. (1996) 'Cybercheating: The Internet Could Become the Newest Battleground in Academic Fraud', The Muse. Retrieved from http://ursu.uregina.ca/_carillon/Sept12.96/feature/feature1.html. Accessed November 1998.

[14] Wood, G. and Warnken P. (2004) 'Managing Technology: Academic Original Sin: Plagiarism, the Internet and Librarians', Journal of Academic Librarianship, vol. 30, no. 3, pp.1-7.

[15] Simkin, M.G. and McLeod, A. (2010) 'Why Do College Students Cheat?', Journal of Business Ethics, vol. 94, pp. 441- 453.

[16] Rosamond, B. (2002) 'Plagiarism, academic norms, and the governance of the profession', Politics, vol. 22, no. 3, pp.167-174.

[17] iNACOL. (2010) National standards for quality online teaching, Vienna, VA: Author. In

Jomon, A.P. and Cochran, J.D. (2013) 'Key interactions for online programs between faculty, students, technologies and educational institutions', The Quarterly Review of Distance Education, Vol. 14, no. 1, pp. 49-62.

[18] Davis, S. F., Kennedy, K., Nowak, S., Raghuramam, R. and Thomas, J. (2000) 'Academic Dishonesty and Distance Learning: Student and Faculty Views', College Student Journal, vol. 34, no. 2, pp. 309-15. 
[19] Robinson-Zañartu, C., Peña, E.D., Cook-Morales, V., Peña, A.M., Afshani, R. and Nguyen, L. (2005) 'Academic crime and punishment: Faculty members' perceptions of and responses to plagiarism', School Psychology Quarterly, vol. 20, no. 3, pp.318-337.

[20] Walker, J. (2010) 'Measuring plagiarism: Researching what students do, not what they say they do', Studies in Higher Education, vol. 35, no. 1, pp. 41-59.

[21] Kelley, K. and Bonner, K. (2005) 'Distance education and academic dishonesty: Faculty and administrator perception and responses', Journal of Asynchronous Learning Network, vol. 9, pp. 43-52.

[22] Burgoon, J., Stoner, M., Bonita, J. and Dunbar, N. (2003) 'Trust and Deception in Mediated Communication', 36th Hawaii International Conference on Systems Sciences, 44a.

[23] Rowe, N. (2004) 'Cheating in online student assessment: Beyond plagiarism', Online Journal of Distance Learning.

[24] Heberling, M. (2004) 'Maintaining academic integrity in online education', Online Journal of Distance Learning Administration, vol. 5.

[25] Kennedy, K., Nowak, S., Raghuraman, R., Thomas, J. and Davis, S.F. (2000) 'Academic dishonesty and distance learning: Student and faculty views', College Student Journal, vol. 34, pp. 309-314.

[26] Ford, R.C. and Richardson, W.D. (1994) 'Ethical decision making: A review of the empirical literature', Journal of Business Ethics, vol. 13, pp.205-221.

[27] Chapman, J.K., Davis, R., Toy, P. and Wright, L. (2004) 'Academic integrity in the business school environment: I'll get by with a little help from my friends', Journal of Marketing Education, vol. 26, no. 3, pp.236-249.

[28] Allmon, D.E., Page, D. and Rpberts, R. (2000) 'Determinants of Perceptions of Cheating: Ethical Orientation, Personality and Demographics', Journal of Business Ethics, vol. 23, no. 4, pp.411-422.

[29] Etter, S., Cramer, J. and Finn, S. (2006) 'Origins of Academic Dishonesty: Ethical Orientations and Personality Factors Associated with Attitudes about Cheating with Information Technology', Journal of Research on Technology in Education, vol. 39, no. 2, pp. 133-155.

[30] Jackson, C. J., Levine, S. Z., Furnham, A. and Burr, N. (2002) 'Predictors of Cheating Behavior at a University: A Lesson From the Psychology of Work', Journal of Applied Social Psychology, vol. 32, pp. 1031-1046.

[31] Sackett, P.R. and Wanek, J.E (1996) 'New developments in the use of measures of honesty, integrity, conscientiousness, dependability, trustworthiness, and reliability for personnel selection', Personnel Psychology, vol. 42, pp. 787- 829.

[32] Christine, Z.J. and James, C.A. (2008) 'Personality Traits and Academic Attributes as Determinants of Academic Dishonesty in Accounting and Non-Accounting College Majors', In the Proceeding of 15th Annual Meeting of American Society of Business and Behavioral Sciences (ASBBS) held on 23-24 February, 2008 at Las Vegas, USA, 15, 604-616.

[33] John, O. P. and Srivsatava, S. (1999) 'The Big Five Trait Taxonomy: History, Measurement and Theoretical Perspectives', In Pervin L and OP Johns (Eds.), Handbook of personality: Theory and Research, pp. 102-138, New York: Guilford.

[34] Williams, K.M., Nathanson, C. and Paulhus, D.L. (2010) 'Identifying and Profiling Scholastic Cheaters: Their Personality, Cognitive Ability \& Motivation', Journal of Experimental Psychology, vol. 16, pp. 293-307.

[35] Digman, J. M. (1990) 'Personality Structure: Emergence of the Five-Factor Model', Annual Review of Psychology, vol. 41, pp. $417-440$.

[36] Goldberg, L.R. (1993) 'The Structure of Phenotypic Personality Traits', American Psychologist, vol. 48, pp. $26-34$.

[37] Costa, P.T. Jr. and McCrae, R.R. (1988) 'Personality in Adulthood: A Six Year Longitudinal Study of Self-Reports and Spouse Ratings on the NEO Personality Inventory', Journal of Personality and Social Psychology, vol. 54, pp. 853-863.

[38] Costa, P.T. Jr. and McCrae, R.R. (1992) Revised NEO Personality Inventory and NEO Five-Factor Inventory Professional Manual (Psychological Assessment Resources, Odessa, FL).

[39] Barrick M.R. and Mount, M.K. (1991) 'The Big Five Personality Dimensions and Job Performance: A Meta-Analysis', Personnel Psychology, vol. 44, pp. 1-26.

[40] Furnham, A., Petrides, K.V., Tsaousis, I. Pappas, K. and Garrod, D. (2005) 'A Cross-Cultural Investigation into the Relationships between Personality Traits and Work Values', The Journal of Psychology, vol. 139, pp. 5-32.

[41] Watson, D. and Hubbard, B. (1996) 'Adaptational Style and Dispositional Structure: Coping in the Context of the 5-Factor Model', Journal of Personality, vol. 64, pp. 737-774. 
[42] O'Fallon, M.J. and Butterfield, K.D. (2011) 'Moral Differentiation: Exploring Boundaries of the "Monkey See, Monkey Do", Perspective', Journal of Business Ethics, vol. 102, pp. 379-399.

[43] Eysenck, H.J. and Eysenck M.W. (ed). (1985) Personality and individual differences: A natural science approach. New York: Plenum Press.

[44] Phillips, A.S. and Bedeian, A.G. (1994) 'Leader-Follower Exchange Quality: The Role of Personal and Interpersonal Attributes', Academy of Management Journal, vol. 37, no. 4, pp. 990-1001.

[45] Aslam, M.S. and Nazir, M.S. (2011) 'The impact of personality traits on academic dishonesty among Pakistan students', The Journal of Commerce, Vol. 3, No. 2.

[46] Cizek, G. J. (1999) 'Cheating on Tests: How to Do It, Detect It, and Prevent It', Erlbaum, Mahwah, NJ.

[47] Singh, U. and Akhtar, S.N. (1972) 'Personality variables and cheating in examinations', India: Tata Institute of Social Sciences, vol. 32, pp. 423-428.

[48] Jensen-Campbell, L.A. and Graziano, W.G. (2005) 'The two faces of temptation: Differing motives for self-control', Merrill-Palmer Quarterly, vol. 51, no. 3, pp. 287-314.

[49] Day, N.E., Hudson, D., Dobies, P.R. and Waris, R. (2011) 'Student or situation? Personality and classroom context as predictors of attitudes about business school cheating', Social Psychology of Education, vol. 14, no. 2, pp. $261-282$.

[50] Davis, S., Pierce, M. C., Yandell, L. R., Arnow, P. S., and Loree, A. (1995). 'Cheating in college and the type a personality: A reevaluation', College Student Journal, vol. 29, no. 4, pp. 493-497.

[51] Colbert A.E., Mount, M.K., Harter, J.K., Witt, L.A. and Barrick, M.R. (2004) 'Interactive Effects of Personality and Perceptions of the Work Situation on Workplace Deviance', Journal of Applied Psychology, vol. 89, pp. 599-609.

[52] Litzky, B.E., Eddleston, K.A. and Kidder, D.L. (2006) 'The Good, the Bad, and the Misguided: How Managers Inadvertently Encourage Deviant Behaviors', Academy of Management Perspectives, vol. 20, pp. 91-103.

[53] Robinson, S.L. and Greenburg, J. (1998) 'Employees Behaving Badly: Dimensions, Determinants, and Dilemmas in the Study of Workplace Deviance', In C.L. Cooper and D.M. Rousseau (Eds.), Trends in organizational behavior, pp. 1-30. Chichester: John Wiley \& Sons.

[54] Organ, D.W. and Lingl, A. (1995) 'Personality, Satisfaction, and Organizational Citizenship Behavior', The Journal of Social Psychology, vol. 135, pp. 339-350.

[55] Trevino, L.K. and Nelson, K.A. (2004) Managing Business Ethics: Straight Talk about How to do it Right (3rd Ed.). Hoboken, NJ: John Wiley \& Sons, Inc.

[56] Gosling, S.D., Rentfrow, P.J. and Swann, W.B., Jr. (2003) 'A very brief measure of the Big Five personality domains', Journal of Research in Personality, vol. 37, pp. 504-528.

[57] Kisamore, J.L., Stone, T.H. and Jawahar, I.M. (2007) 'Academic integrity: The relationship between individual and situational factors on misconduct contemplations', Journal of Business Ethics, vol. 75, pp. 381-394.

[58] Stuber-McEwen, D., Wiseley, P. and Hoggatt, S. (2009) 'Point, Click, and Cheat: Frequency and Type of Academic Dishonesty in the Virtual Classroom', 2009.

[59] Peled, Y., Barczyk, C., Eshet, Y., and Grinautski, K. (2012) 'Learning Motivation and Student Academic Dishonesty - A Comparison between Face-To-Face and Online Courses', In P. Resta (Ed.), Proceedings of Society for Information Technology \& Teacher Education International Conference 2012 (pp. 752-759). Chesapeake, VA: AACE.

[60] McCabe, D.L., Feghali, T. and Abdallah, H. (2008) 'Academic Dishonesty in the Middle East: Individual and Contextual Factors', Research in Higher Education, vol. 49, no. 5, pp. 451-467.

[61] Rawwas, M., Al-Khatib, J. and Vitell, S. (2004) 'Academic Dishonesty: A Cross-Cultural Comparison of U.S. and Chinese Marketing Students', Journal of Marketing Education, vol. 26, pp. 89-100.

[62] Grimes, P.W. (2004) 'Dishonesty in Academics and Business: A Cross-Cultural Evaluation of Student Attitudes', Journal of Business Ethics, vol. 49, pp. 273-290. 